Article

\title{
Impact of Combined Sewer Overflow on Wastewater Treatment and Microbiological Quality of Rivers for Recreation
}

\author{
Franz Mascher, Wolfgang Mascher, Franz Pichler-Semmelrock, Franz F. Reinthaler, \\ Gernot E. Zarfel (iD and Clemens Kittinger* \\ Institute for Hygiene, Microbiology and Environmental Medicine, Medical University of Graz, \\ 8020 Graz, Austria; franz.mascher@medunigraz.at (F.M.); wolfgang.mascher@medunigraz.at (W.M.); \\ franz.pichler-semmelrock@stmk.gv.at (F.P.-S.); franz.reinthaler@medunigraz.at (F.F.R.); \\ gernot.zarfel@medunigraz.at (G.E.Z.) \\ * Correspondence: clemens.kittinger@medunigraz.at; Tel.: +43-316-3857-3600
}

Received: 20 October 2017; Accepted: 16 November 2017; Published: 22 November 2017

\begin{abstract}
Within the framework of a one-year study the treatment capacity of a municipal wastewater treatment plant (WWTP) was evaluated, with regard to fecal indicator bacteria (FIB) and to their influence on the recipient. The logarithmic reduction rates for fecal coliforms (FC), Escherichia coli (EC) and intestinal enterococci (IE) were 2.84, 2.90 and 2.93. In the investigated period of time, the tested treatment plant released $4.3 \%$ of the total annual load flow volume as combined sewer overflow (CSO), that is, when the influent into the combined sewer exceeds the capacity of the treatment plant and coarsely cleaned wastewater arrives at the recipient. This CSO discharge increased the number of FIB significantly by $1.2 \times 10^{2} \mathrm{MPN} / 100 \mathrm{~mL}$ for EC, and by $1.8 \times 10^{1} \mathrm{MPN} / 100 \mathrm{~mL}$ for IE. For the Styrian part of the Mur River (1.6 million inhabitants), a calculation of FIB of all sewage treatment plants estimating the same ratio of $\mathrm{CSO}(4.3 \%)$ and a given mean flow rate $(\mathrm{QM})$ results in a significant increase of the FIB load in the recipient: $3.8 \times 10^{3} \mathrm{MPN} / 100 \mathrm{~mL}$ for EC and $5.8 \times 10^{2} \mathrm{MPN} / 100 \mathrm{~mL}$ for IE. On the basis of these values the standards of water quality for recreational purposes cannot be met.
\end{abstract}

Keywords: combined sewer; wastewater treatment; microbiological quality; surface water; river

\section{Introduction}

Continual efforts in improving the water quality over the last decades and the national implementation of European Directives have been successful. The quality of the Mur River has improved and risen from IV to II according to the saprobic system [1,2], most effectively through the implementation of wastewater treatment plants in the catchment area. Today, $85 \%$ of the population within the catchment area are connected to central sewage treatment plants, and this was the main reason for the improvement of the river water quality. Nevertheless, the level of fecal indicator bacteria (FIB) could not be reduced to the quality levels required by the bathing water regulation [3]. A previous study carried out by Kittinger et al. investigated the Mur River concerning its burden of fecal bacteria-like fecal coliforms (FC), Escherichia coli (EC), intestinal enterococci (IE) and Salmonella spp. [4]. In this study the water quality was investigated monthly over a period of a year at 21 sampling sites on the Mur River. The microbiological data showed a massive burden of FIB, with an increasing load of bacteria in the flow direction and seasonal fluctuation. Interpreting these values on the basis of the European bathing water regulation [5], the Mur River is not suitable for recreation or water sports. Studies on other European rivers show comparable results [6-8]. Outbreak sof zoonosis among sporting events in rivers and the evidence of multiresistant bacteria underline the improper quality of river water for recreational purposes [9-11]. 
This discrepancy between the good status of the Mur River according to the saprobic system and the high values of FIB provided the impulse for the present study. The state of a specific technology wastewater treatment plant (WWTP) was investigated according to its purification capacity and the influence of the treated wastewater on the recipient. On the basis of validated, mathematical methods, the acquired data thus made it possible to quantify the treatment capacity of a municipal WWTP concerning FIB. Furthermore, the results of this study pinpointed the FIB load that is delivered by the influent of communal WWTPs to the recipient (Mur River).

\section{Material and Methods}

\subsection{Description of the Wastewater Treatment Plant (WWTP)}

The investigated WWTP is of the mechanical-biological type with anaerobic sludge stabilization, providing municipal and industrial wastewater services for 50,000 population equivalents at $\mathrm{N} 46^{\circ} 43^{\prime} 3^{\prime \prime} / \mathrm{E} 15^{\circ} 37^{\prime} 31^{\prime \prime}$. It uses a single stage with denitrification, biological and chemical phosphor elimination, activated sludge separation and finally postfiltration for micro-flocculation retention. The sewage system is a partly mixed but mostly separated draining system; detailed information is given in Table 1.

Table 1. Specific parameters of the investigated wastewater treatment plant (WWTP).

\begin{tabular}{cc}
\hline Parameters & Detail Information \\
\hline Connected Inhabitants & 50,000 \\
Hydraulic load Q QW & $8000 \mathrm{~m}^{3} /$ day \\
Hydraulic load Q Q & $16,000 \mathrm{~m}^{3} /$ day \\
Max. Q & $140 \mathrm{~L} / \mathrm{s}$ \\
Max.Q & $280 \mathrm{~L} / \mathrm{s}$ \\
(total input activation reservoir) & $3000 \mathrm{~kg} /$ day \\
BOD load & $6000 \mathrm{~kg} /$ day \\
COD load & $550 \mathrm{~kg} /$ day \\
N $_{\text {tot. load }}$ & $75 \mathrm{~kg} /$ day \\
\hline
\end{tabular}

Notes: Max. QDW: Maximum dry weather influent; Max. $\mathrm{Q}_{\mathrm{RW}}$ : Maximum rainy weather influent; BOD5 load: biological oxygen demand (5 days); COD load: chemical oxygen demand; $\mathrm{N}_{\text {tot. }}$ load: total nitrogen; $\mathrm{P}_{\text {tot. }}$ load: total phosphor.

Characteristic parts of the water treatment line:

- Coarse gravel, combined sewage basin $\left(3000 \mathrm{~m}^{3}\right)$

- Influent lifting: Archimedean screws (three aggregates with $140 \mathrm{~L} / \mathrm{s}$ max. capacity each)

- Rake system: Two lines (3 mm gap size) $280 \mathrm{~L} / \mathrm{s}$ each

- Sand washing plant, sewage take-up, fecal, foreign sludge/mud and grease take-up

- Sand and grease catchment; two lines

- Two primary clarifiers with $126 \mathrm{~m}^{3}$ each, and a distribution building

- Aeration basins (two lines) for single-step activated sludge processing, with combined pre-installed and simultaneous denitrification, as well as biological phosphor elimination; $\mathrm{V}_{\text {tot. }}=5.100 \mathrm{~m}^{3}$

- Two rectangular, secondary clarification basins with vertical flow-through: $\mathrm{V}_{\text {tot. }}=4.032 \mathrm{~m}^{3}$ each

- Precipitation station: iron-aluminum combination

- Filter system: disc filter system for solid retention, three units of $60 \mathrm{~m}^{2}$ each and with a max. load of $1000 \mathrm{~m}^{3} / \mathrm{h}$.

Characteristic parts of the sludge-line:

- Pre-thickener of the sewage sludge 
- Sludge mixing container for transfer to the digestion tower $\left(100 \mathrm{~m}^{3}\right)$

- Digestion tower: $\mathrm{V}=1500 \mathrm{~m}^{3}$

- High-performance centrifuge for sludge dewatering, and a belt thickener for surplus sludge $30 \mathrm{~m}^{3} / \mathrm{h}$, sludge storage

- Sewer gas unit consisting of a digesting tower (anaerobic treatment), condensation dryer, active-carbon plant, measuring unit, gas desulphurization, gas tank, gas flare, heating boiler and a gas power station.

\subsection{Sample Collection and Investigated Parameters}

First, $250 \mathrm{~mL}$ of wastewater and $100 \mathrm{~g}$ of sludge were collected weekly for one year (October 2012-September 2013, N = 54). The samples were both taken from the untreated and treated wastewaters and from the sludge before and after anaerobic stabilization. Transport to the laboratory was cooled and microbiological parameters were analyzed the same day.

Fecal indicator bacteria (FIB) were determined out of $100 \mathrm{~mL}$ (after preparing appropriate dilutions) using the Colilert 18 System for fecal coliforms (FC) and Escherichia coli (EC) (ISO 9308-2, [12]), and the Enterolert 18 System for intestinal enterococci (IE) (ISO 7899-2, [13]) according to the manufacturer's instructions (IDEXX, Ludwigsburg, Germany). Salmonella were detected out of $100 \mathrm{~mL}$ wastewater and $10 \mathrm{~g}$ of sludge by an enrichment procedure according to (ISO 19250 [14]).

Statistical significance for all data, as well as median and standard deviation of the median, were calculated with GraphPadPrism ${ }^{\mathrm{TM}} 6.0$ for Windows, GraphPad Software, San Diego, CA, USA, www.graphpad.com.

\section{Results}

\subsection{Bacterial Load and Reduction Rate of the Wastewater}

The annual median of the influent concentration of FC $\left(5.79 \times 10^{6} \mathrm{MPN} / 100 \mathrm{~mL}\right)$ and EC $\left(4.10 \times 10^{6} \mathrm{MPN} / 100 \mathrm{~mL}\right)$ showed the same order of magnitude. The median for IE was one $\log$ below $\left(7.26 \times 10^{5} \mathrm{MPN} / 100 \mathrm{~mL}\right)$. Although the samples were taken weekly for one year with different meteorological conditions, the values were within a narrow range $(0.61 \mathrm{MPN} / 100 \mathrm{~mL}$ to $0.82 \mathrm{MPN} / 100 \mathrm{~mL} \log$ for the inter percentile range, and $0.26 \mathrm{MPN} / 100 \mathrm{~mL}$ to $0.38 \mathrm{MPN} / 100 \mathrm{~mL}$ $\log$ for inter quartile). The influent of FIB to the WWTP was constant over the investigation period (Figure 1, Table 2).

The median values at the discharge site were also quite similar, with $8.36 \times 10^{3} \mathrm{MPN} / 100 \mathrm{~mL}$ for FC and $5.21 \times 10^{3} \mathrm{MPN} / 100 \mathrm{~mL}$ for EC. The median for IE was one log below at $7.50 \times 10^{2} \mathrm{MPN} / 100 \mathrm{~mL}$. The reduction rates for the investigated FIB were $2.84 \log$ for FC, $2.90 \log$ for EC and $2.93 \mathrm{log}$ for IE (calculated on base of median values of influent and discharge). Although IE are present on a lower level in the influent, their reduction rate does not differ (significantly) from the reduction rates of FC and EC. Compared to the inflow, values for the discharge site are more disperse: $1.05 \log$ MPN/100 mL to $1.39 \log$ MPN/100 mL for percentiles, and $0.62 \log$ MPN/100 mL to $0.75 \log$ MPN/100 $\mathrm{mL}$ for the quartile (Figure 1, Table 2). This difference was probably caused by weather influence or plant-specific conditions.

Qualitative detection of Salmonella spp. in $100 \mathrm{~mL}$ wastewater led to over $50 \%$ of influent samples testing positive. After the biological treatment stage at the discharge side, $30 \%$ of the samples could test positive for Salmonella spp. 
Table 2. Range (Logarithmic steps) between 10\% and 90\% Perzentile and Quartiles (25\% and 75\%) for fecal coliforms (FC), Escherichia coli (EC) and intestinal enterococci (IE) in the waste water untreated and waste water treated $\mathrm{WWu}$ and $\mathrm{WWt}$, and linear and logarithmic reduction rates (RR) (MPN/100 mL).

\begin{tabular}{cccc}
\hline Investigated Parametere & WWu (10-90/25-75) & WWt (10-90/25-75) & RR (log) \\
\hline FC & $0.82 / 0.38$ & $1.05 / 0.62$ & 2.84 \\
EC & $0.76 / 0.32$ & $1.07 / 0.58$ & 2.90 \\
IE & $061 / 0.26$ & $1.39 / 0.75$ & 2.93 \\
\hline
\end{tabular}

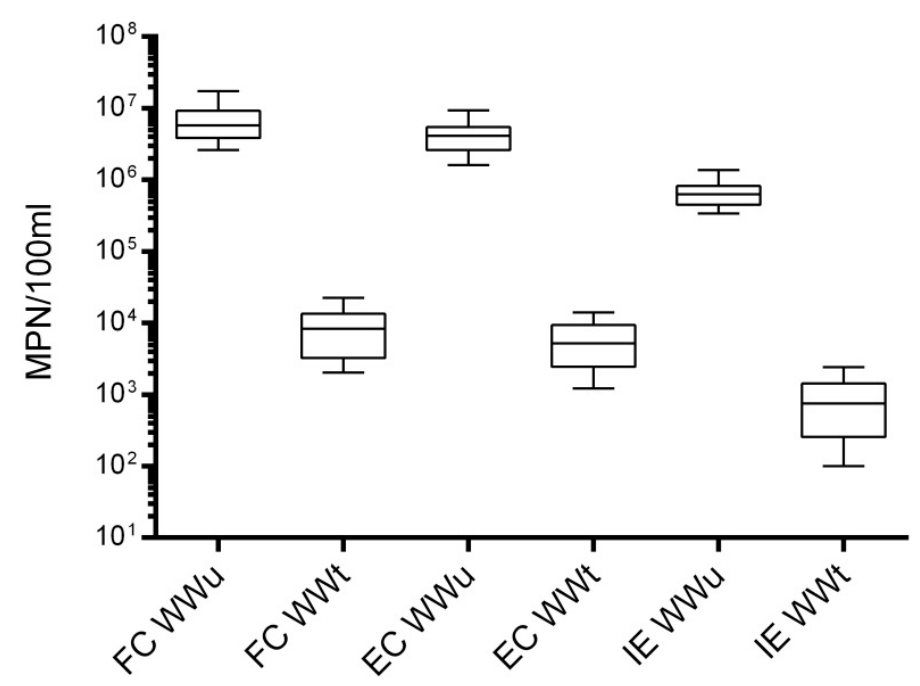

Figure 1. Number (MPN/100 mL) of FC, EC und IE in the untreated wastewater (WWu) and in the treated wastewater $(\mathrm{WWt}$ ) (annual average, 90th percentile, $p=0.0001)$. Values are presented in a box (25th, 50th and 75th percentile) and whiskers (10th and 90th percentile) chart, $(\mathrm{N}=54)$.

\subsection{Bacterial Load and Reduction Rate of the Sewage Sludge}

Over a one-year investigation period, the median values of FIB for raw sewage sludge (SSr) were $7.94 \times 10^{5} \mathrm{MPN} / \mathrm{g}$ for FC, $4.41 \times 10^{5} \mathrm{MPN} / \mathrm{g}$ for EC and $1.60 \times 10^{5} \mathrm{MPN} / \mathrm{g}$ for IE, all in a comparable magnitude.

Median values for stabilized sewage sludge (SSs) were $3.84 \times 10^{2} \mathrm{MPN} / \mathrm{g}$ for FC, $2.20 \times 10^{2} \mathrm{MPN} / \mathrm{g}$ for EC and $1.01 \times 10^{3} \mathrm{MPN} / \mathrm{g}$ for IE. The number of IE was high in the SSs, which was the reverse of the treated wastewater. The reduction rate was $3.22 \mathrm{log} \mathrm{MPN} / \mathrm{g}$ for FC, and EC. IE were reduced only by $2.2 \log$ MPN/g. The high reduction rates had also high standard deviations of up to two log orders. This may be due to changing conditions in the course of sludge stabilization (Figure 2 and Table 3).

SSr sludge was tested positive for Salmonella in $66 \%$ of all samples, and sludge stabilization reduced this ratio to $26 \%$. 


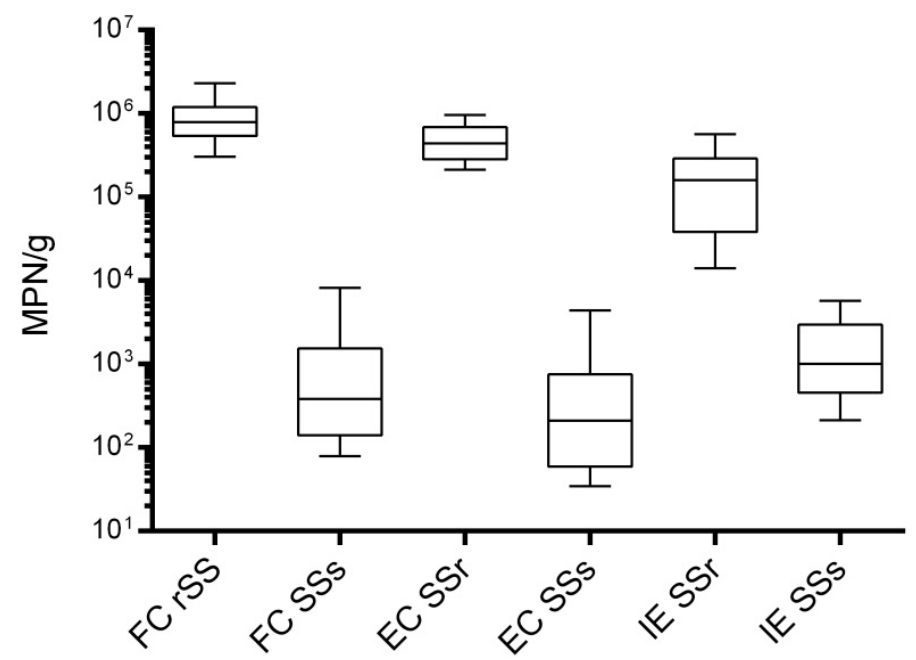

Figure 2. Concentrations of FC, EC and IE in the raw sewage sludge (SSr) and stabilized sludge (SSs), $(\mathrm{N}=54)$.

Table 3. 10th and 90th percentile and quartile (25\% and 75\%) values for FC, EC and IE in the SSr and SSs, and reduction rates for FC, EC and IE (median, logarithmic vs. linear) in SSs in comparison to $\mathrm{SSr}(\mathrm{MPN} / \mathrm{g})$.

\begin{tabular}{cccc}
\hline Investigated Parameter & SSr (10-90/25-75) & SSs (10-90/25-75) & RR (log) \\
\hline FC & $0.88 / 0.35$ & $2.01 / 1.04$ & 3.32 \\
EC & $0.66 / 0.39$ & $2.11 / 1.11$ & 3.32 \\
IE & $1.61 / 0.88$ & $1.43 / 0.82$ & 2.20 \\
\hline
\end{tabular}

\subsection{Calculation of FIB Increase in the Recipient on the Basis of WWt and Combined Sewer Overlfow (CSO)}

The results of this study form the basis for developing a formula for the calculation of FIB impact on rivers. If the boundary conditions are known, this formula can be used to predict every single FIB impact on surface waters, no matter if the impact was caused by one single WWTP site or by the total discharge of WWTPs along a river. Different scenarios, from totally WWu to partially WWt and different contamination sources, can be simulated.

The results can then be used to simulate the efficiency of wastewater treatment along a river.

$$
C_{R}=\frac{C_{w w} \times W_{\mathrm{v}} \times \mathrm{X}+\mathrm{CWw}_{\mathrm{u}} \times \mathrm{WW}_{\mathrm{v}} \times(1-\mathrm{X})}{\mathrm{R}_{\mathrm{v}}}
$$

$C_{R}(M P N / 100 \mathrm{~mL})$ : Increase of FIB in the recipient as a result of influent of treated and untreated WW $\mathrm{C}_{W W t}(\mathrm{MPN} / 100 \mathrm{~mL}$ ): Concentration of FIB in treated waste water WW

$\mathrm{C}_{W W u}(\mathrm{MPN} / 100 \mathrm{~mL})$ : Concentration of FIB in untreated WW $\mathrm{WW}_{\mathrm{V}}\left(\mathrm{m}^{3} / \mathrm{t}\right)$ : total volume of WW per time in the WWTP $\mathrm{R}_{\mathrm{V}}\left(\mathrm{m}^{3} / \mathrm{t}\right)$ : discharge of the recipient per time $X$ : Clearance ratio regarding treated and untreated WW; value between 0 and 1

\subsection{WWTP Purification Efficiency and Its Influence on the Recipient}

The mean reduction rate of FIB of the investigated WWTP is high and consistent compared to results from other countries [7,15]. In these studies, the reduction rate was between 0.7 and $3.5 \mathrm{log}$ orders, depending on the size and technical features of the WWTPs. The good reduction efficacy is due to multi-step treatment and retention time within the WWTP. The total one-year flow volume of the WWTP was $3113.092 \mathrm{~m}^{3}$, which resulted in a daily flow-through of $8.529 \mathrm{~m}^{3}=0.1 \mathrm{~m}^{3} / \mathrm{s}$, and this 
volume is directly discharged into the recipient (Mur River). On the basis of the mean flow rate (QM) of the Mur River of $144.6 \mathrm{~m}^{3} / \mathrm{s}$, and the flow rate for low water of $63.82 \mathrm{~m}^{3}\left(\mathrm{Q}_{95}\right) \%$ [16], a dilution factor (DF) for the discharged treated wastewater for QM and $\mathrm{Q}_{95 \%}$ of 1446 and 638 can be calculated. Based on this dilution factor, a negligible elevation of FC, EC and IE, on the basis of median values, can be observed for mean flow rates, as well as for $\mathrm{Q}_{95 \%}$ (Table 4).

Table 4. Increase of FIB-number in the recipient (MPN/100 mL) by the WWTP discharge (median and $90 \%$-Percentile for FC, EC and IE) calculated on basis of the mean flow rate (QM) or $\mathrm{Q}_{95} \%$.

\begin{tabular}{cccc}
\hline \multirow{2}{*}{ Flow Rate } & FC & EC & IE \\
& (Median/90th Percentile) & (Median/90th Percentile) & (Median/90th Percentile) \\
\hline QM & $5.8 / 15.5$ & $3.6 / 9.8$ & $0.5 / 1.7$ \\
$\mathrm{Q}_{95 \%}$ & $13.1 / 35.2$ & $8.2 / 22.1$ & $1.2 / 3.8$ \\
\hline
\end{tabular}

\subsection{Combined Sewer Overflow (CSO) and Its Influence on the Recipient}

Based on the calculation of treated wastewater, the same calculation was carried out for CSO, which leads to a dramatic increase of the FIB in the recipient (Table 4). Such conditions can occur when heavy rainfall causes too much influent which exceeds the volume capacity of the WWTP. Thus, untreated or coarsely treated wastewater flows directly into the recipient. In the investigated WWTP, CSO with a volume of $4.3 \%$ of the annual flow occurred. Converted into the annual load this leads to 30- to 37-fold increase of the recipient Mur River (Tables 5 and 6). The calculated bacterial load is probably slightly lower than in practice because the coarse mechanical pre-purification reduces the number of microorganisms by sedimentation. When we investigated FIB of CSO samples in our study (on a random basis), the FIB number did not differ from untreated wastewater. This might be due to the limited retention volume of the WWTP, which leads to a dilution factor that is just twoto threefold and, therefore, it is not that strongly reflected in the FIB number. A study carried out by Kistemann et al. 2008, also calculated a 20-fold increase of FIB in the recipient for CSO (15).

Table 5. Increase of the FIB number $(\mathrm{MPN} / 100 \mathrm{~mL})$ caused by the direct discharge of untreated wastewater (median and 90th Percentile of FC, EC, IE) at QM and $\mathrm{Q}_{95 \%}$.

\begin{tabular}{cccc}
\hline \multirow{2}{*}{ Flow Rate } & FC & EC & IE \\
& (Median/90th Percentile) & (Median/90th Percentile) & (Median/90th Percentile) \\
\hline QM & $4004 / 11,964$ & $2835 / 6420$ & $436 / 947$ \\
$\mathrm{Q}_{95 \%}$ & $9075 / 27,116$ & $6426 / 14,551$ & $989 / 2147$ \\
\hline
\end{tabular}

Table 6. Annual load of the Mur River for FC, EC and IE (median) for WWt, combined sewer overflow (CSO), and impact factor WWt/CSO (MPN/100 mL).

\begin{tabular}{cccc}
\hline Annual Load & FC & EC & IE \\
\hline WWt & $2.6 \times 10^{14}$ & $1.6 \times 10^{14}$ & $2.3 \times 10^{13}$ \\
CSO & $7.8 \times 10^{15}$ & $5.5 \times 10^{15}$ & $8.5 \times 10^{14}$ \\
Factor $_{(\mathrm{CSO} / \mathrm{WWt})}$ & 30 & 34 & 37 \\
\hline
\end{tabular}

\subsection{Anaerobic Sludge-Stabilization}

Sludge stabilization reduced the investigated fecal indicator bacteria by $3.32 \log \mathrm{MPN} / \mathrm{g}$ (FC, EC, on the basis of the median-values), but only $2.20 \log \mathrm{MPN} / \mathrm{g}$ for IE, which is due to the higher environmental resistance of IE. The high reduction rates for FC and EC are accompanied by a high dispersion of the values (two log orders, Table 2), which indicates inhomogeneous and changing conditions during sludge stabilization. This hypothesis is also supported by the lower reduction rate of IE, which was not seen in the wastewater. This must therefore be related to the ecological conditions 
in the sewage sludge. The short residence time (about one day) during wastewater treatment does not inactivate bacteria, but only separates the bacterial load in sewage sludge and wastewater. The annual load for IE for the wastewater intake was $9.0 \times 10^{15} \mathrm{MPN} / 100 \mathrm{~mL}$, and the annual load for raw sludge was $2.1 \times 10^{15} \mathrm{MPN} / \mathrm{g}$. A substantial part of IE of the untreated wastewater could be identified in the raw sludge.

The Styrian sewage sludge regulation [17] defines the epidemiological harmlessness of sewage sludge with an absence of Salmonella spp. and a maximum of 100 EC per g. In our study, on the other hand, Salmonellae could be detected quantitatively in $26.4 \%$ of the stabilized sludge samples, and the median for E. coli was $210 / \mathrm{g}$. Therefore, despite the reduction of FC and EC of three log orders the final product is not sanitized and harmless.

\section{Discussion and Conclusions}

The discharge of treated wastewater into the recipient with a CSO percentage of $4.3 \%$ of the total discharge increased the number of FIB significantly by $1.2 \times 10^{2} \mathrm{MPN} / 100 \mathrm{~mL}$ for EC and by $1.8 \times 10^{1} \mathrm{MPN} / 100 \mathrm{~mL}$ for IE. This need not automatically lead to exceeding the bathing water limits of the recipient regarding low basal levels of FIB in the recipient and a fairly even distribution of CSO over the whole year. This result, however, is only valid for the investigated WWTP and the corresponding stretch of the river.

For the evaluation of the whole course of the river all other WWTPs and CSO events have to be taken into account. The Styrian part of the Mur River (around $300 \mathrm{~km}$ ) harbors wastewater treatment plants for $1.6 \mathrm{~m}$ people, regardless of the tributaries. A calculation of FIB of all sewage treatment plants estimating the same ratio of CSO $(4.3 \%)$ and a mean flow rate (QM) near the Slovenian border of $149 \mathrm{~m}^{3} / \mathrm{s}$ (long-term annual average) results in a significant increase of the FIB load in the recipient (Table 6). A CSO proportion of $4.3 \%$ of the total water flow reduces the purification efficacy from 2.90 to $1.37 \log$ MPN/100 mL. Considering CSO, the microbiological standards required for bathing waters as required by the European Union [5] cannot be achieved for the Mur River. Similar results were obtained by studies on other European rivers as well [7,18-21].

The sole discharge of treated wastewater without CSO would increase the water quality of the Mur River substantially; even if all WWTP are taken into account, bathing water quality would be maintained. The influent of only untreated WW, on the other hand, would decrease the water quality dramatically (Table 7).

Table 7. Impact of $4.3 \%$ CSO, 100\% treated wastewater and $100 \%$ untreated wastewater on the total course of the Mur River. Increase of EC and IE (MPN/100 mL) was calculated out of the median values of the mean discharge for the investigated WWTP and the sum of all WWTP $\left(\sum\right)$.

\begin{tabular}{ccccc}
\hline Wastewater Treatment & \multicolumn{2}{c}{ EC (MPN/100 mL) } & \multicolumn{2}{c}{ IE (MPN/100 mL) } \\
\hline & WWTP & $\sum$ WWTP & WWTP & $\sum$ WWTP \\
\hline $\begin{array}{c}\text { Treated WW } \\
\text { CSO } \\
(4.3 \%)\end{array}$ & $1.2 \times 10^{2}$ & $3.8 \times 10^{3}$ & $1.8 \times 10^{1}$ & $5.8 \times 10^{2}$ \\
\hline $\begin{array}{c}\mathrm{CSO}_{(0 \%)} \\
\text { Treated WW }_{(100 \%)}\end{array}$ & $3.5 \times 10^{0}$ & $1.1 \times 10^{2}$ & $0.5 \times 10^{0}$ & $1.2 \times 10^{1}$ \\
\hline $\begin{array}{c}\mathrm{CSO}_{(10 \%)} \\
\text { Treated WW }\end{array}(0 \%)$ & $2.8 \times 10^{3}$ & $8.7 \times 10^{4}$ & $4.3 \times 10^{2}$ & $1.3 \times 10^{4}$ \\
\hline
\end{tabular}

This calculation does not consider other factors that also lead to a decrease of FIB, like mortality rates of bacteria in natural aquatic systems, biotic factors like grazing by protozoan-plankton, or abiotic factors like the influence of sunlight on them (summed up under the term of "river self-purification"). Sunlight is the most important factor as it reduces FIB by one log within hours, as long as the turbidity of the water is low [22-25]. 
Neither does it take factors into account that lead to an increase of FIB, for example, non-point sources like surface runoff and soil leaching. The influence of these sources is due to the usage of the surrounding landscape (woods, or livestock pastures). Moreover, the intensity and amount of rainfall and the resulting soil runoff also severely influence the input of fecal bacteria into the river. Studies on tributaries of the River Seine showed that $50 \%$ of the fecal bacterial load were caused by non-point sources, and this influence has to be considered to a much higher extent when we observe freshly distributed liquid manure in combination with heavy rainfall [26-28].

Even without other contamination sources taken into consideration, the current practice to accept CSOs does not meet the microbiological standards required for bathing waters, a finding which is underlined by studies carried out on other European rivers $[18,29,30]$. Also, the repeated outbreaks of leptospirosis among sporting events underline the improper microbiological quality of river water for recreational purposes [10,31].

Wastewater treatment according to state of the art techniques leads to a massive reduction of organic and inorganic pollutants and is able to improve the quality of rivers and lakes. Additional treatment steps in terms of wastewater disinfection, as used for river restoration of the Isar River [32], have proved ineffective as the increase of the bacterial load of the recipient by the discharge of proper state of the art cleaned wastewater is low anyway. Instead of additional disinfection measures of treated wastewater, substantial improvement regarding the reduction of FIB in the course of WWt can only be achieved by a drastic reduction of $\mathrm{CSO}$, which reduces the peak load as well as the annual bacterial load. Further measures to reduce runoff of fecal bacteria and organic compounds could be the establishment of protected areas along the river side with a more careful agricultural management. Summing up, the reduction or avoidance of CSO in combination with careful riverside management would represent the most effective measures to reduce FIB in the recipient.

Author Contributions: C.K., F.M. wrote the manuscript and designed the study, F.P.-S., F.F.R. and G.E.Z. proofread the manuscript, W.M. laboratory work, experiments.

Conflicts of Interest: The authors declare no conflict of interest.

\section{References}

1. The Austrian Federal Ministry of Agriculture, Forestry Environment and Water Management. National Water Management Plan 2009—NWMP 2009; Federal Ministry of Agriculture, Forestry, Environment and Water Management: Vienna, Austria, 2009.

2. European Community. Directive 2000/60/EC of the European Parliament and of the Council of 23 October 2000 Establishing a Framework for Community Action in the Field of Water Policy; European Community: Copenhagen, Denmark, 2000.

3. Mose, J.R.; Thiel, W. Evidence of Salmonellae in the Mur River; Comparison 1969-1981. Zentralbl. Bakteriol. Mikrobiol. Hyg. B 1982, 176, 562-570. [PubMed]

4. Kittinger, C.; Marth, E.; Reinthaler, F.F.; Zarfel, G.; Pichler-Semmelrock, F.; Mascher, W.; Mascher, G.; Mascher, F. Water Quality Assessment of a Central European River-Does the Directive 2000/60/EC Cover all the Needs for a Comprehensive Classification? Sci. Total Environ. 2013, 447, 424-429. [CrossRef] [PubMed]

5. European Community. Directive 2006/7/EC OF the European Parliament and of the Council of 15 February 2006 Concerning the Management of Bathing Water Quality and Repealing Directive 76/160/EEC; European Community: Copenhagen, Denmark, 2006.

6. Schindler, P.R. Hygiene of Bathing Waters. Gesundheitswesen 2001, 63 (Suppl. 2), S142-S150. [CrossRef] [PubMed]

7. Servais, P.; Garcia-Armisen, T.; George, I.; Billen, G. Fecal Bacteria in the Rivers of the Seine Drainage Network (France): Sources, Fate and Modelling. Sci. Total Environ. 2007, 375, 152-167. [CrossRef] [PubMed]

8. Kistemann, T.; Rind, E.; Koch, C.; Classen, T.; Lengen, C.; Exner, M.; Rechenburg, A. Effect of Sewage Treatment Plants and Diffuse Pollution on the Occurrence of Protozoal Parasites in the Course of a Small River. Int. J. Hyg. Environ. Health 2012, 215, 577-583. [CrossRef] [PubMed] 
9. Morgan, J.; Bornstein, S.L.; Karpati, A.M.; Bruce, M.; Bolin, C.A.; Austin, C.C.; Woods, C.W.; Lingappa, J.; Langkop, C.; Davis, B.; et al. Outbreak of Leptospirosis among Triathlon Participants and Community Residents in Springfield, Illinois, 1998. Clin. Infect. Dis. 2002, 34, 1593-1599. [CrossRef] [PubMed]

10. Radl, C.; Muller, M.; Revilla-Fernandez, S.; Karner-Zuser, S.; de Martin, A.; Schauer, U.; Karner, F.; Stanek, G.; Balcke, P.; Hallas, A.; et al. Outbreak of Leptospirosis among Triathlon Participants in Langau, Austria, 2010. Wien. Klin. Wochenschr. 2011, 123, 751-755. [CrossRef] [PubMed]

11. Zarfel, G.; Lipp, M.; Gurtl, E.; Folli, B.; Baumert, R.; Kittinger, C. Troubled Water Under the Bridge: Screening of River Mur Water Reveals Dominance of CTX-M Harboring Escherichia Coli and for the First Time an Environmental VIM-1 Producer in Austria. Sci. Total Environ. 2017, 593, 399-405. [CrossRef] [PubMed]

12. Water Quality-Enumeration of Escherichia coli and Coliform Bacteria_Part 2: Most Probable Number Method (ISO 9308-2); International Organization for Standardization: Geneva, Switzerland, 2012.

13. Water Quality-Detection and Enumeration of Intestinal Enterococci-Part 2: Membrane Filtration Method (ISO 7899-2); International Organization for Standardization: Geneva, Switzerland, 2000.

14. Water Quality_Detection of Salmonella spp., ISO 19250; International Organization for Standardization: Geneva, Switzerland, 2010.

15. Kistemann, T.; Rind, E.; Rechenburg, A.; Koch, C.; Classen, T.; Herbst, S.; Wienand, I.; Exner, M. A Comparison of Efficiencies of Microbiological Pollution Removal in Six Sewage Treatment Plants with Different Treatment Systems. Int. J. Hyg. Environ. Health 2008, 211, 534-545. [CrossRef] [PubMed]

16. Ministry for Agriculture, Forestry, Environment and Water Management. Hydrographical Annual of Austria; Ministry for Agriculture, Forestry, Environment and Water Management: Vienna, Austria, 2013.

17. Styrian Government. The Legal Information System of the Republic of Austria 2007; Styrian Government: Styria, Austria, 2007.

18. Kistemann, T.; Schmidt, A.; Flemming, H.C. Post-Industrial River Water Quality-Fit for Bathing again? Int. J. Hyg. Environ. Health 2016, 219, 629-642. [CrossRef] [PubMed]

19. Rechenburg, A.; Koch, C.; Classen, T.; Kistemann, T. Impact of Sewage Treatment Plants and Combined Sewer Overflow Basins on the Microbiological Quality of Surface Water. Water Sci. Technol. 2006, 54, 95-99. [CrossRef] [PubMed]

20. Rechenburg, A.; Kistemann, T. Sewage Effluent as a Source of Campylobacter Sp. in a Surface Water Catchment. Int. J. Environ. Health Res. 2009, 19, 239-249. [CrossRef] [PubMed]

21. Strathmann, M.; Horstkott, M.; Koch, C.; Gayer, U.; Wingender, J. The River Ruhr-An Urban River under Particular Interest for Recreational use and as a Raw Water Source for Drinking Water: The Collaborative Research Project "Safe Ruhr"-Microbiological Aspects. Int. J. Hyg. Environ. Health 2016, 219, 643-661. [CrossRef] [PubMed]

22. Deller, S.; Mascher, F.; Platzer, S.; Reinthaler, F.F.; Marth, E. Effect of Solar Radiation on Survival of Indicator Bacteria in Bathing Waters. Cent. Eur. J. Public Health 2006, 14, 133-137. [PubMed]

23. Kim, G.; Hur, J. Mortality Rates of Pathogen Indicator Microorganisms Discharged from Point and Non-Point Sources in an Urban Area. J. Environ. Sci. 2010, 22, 929-933. [CrossRef]

24. Chigbu, P.; Gordon, S.; Strange, T. Influence of Inter-Annual Variations in Climatic Factors on Fecal Coliform Levels in Mississippi Sound. Water Res. 2004, 38, 4341-4352. [CrossRef] [PubMed]

25. Menon, P.; Billen, G.; Servais, P. Mortality Rates of Autochthonous and Fecal Bacteria in Natural Aquatic Ecosystems. Water Res. 2003, 37, 4151-4158. [CrossRef]

26. Ibekwe, A.M.; Ma, J.; Murinda, S.E. Bacterial Community Composition and Structure in an Urban River Impacted by Different Pollutant Sources. Sci. Total Environ. 2016, 566, 1176-1185. [CrossRef] [PubMed]

27. Franke, C.; Rechenburg, A.; Baumanns, S.; Willkomm, M.; Christoffels, E.; Exner, M.; Kistemann, T. The Emission Potential of Different Land Use Patterns for the Occurrence of Coliphages in Surface Water. Int. J. Hyg. Environ. Health 2009, 212, 338-345. [CrossRef] [PubMed]

28. George, I.; Anzil, A.; Servais, P. Quantification of Fecal Coliform Inputs to Aquatic Systems through Soil Leaching. Water Res. 2004, 38, 611-618. [CrossRef] [PubMed]

29. Touron, A.; Berthe, T.; Gargala, G.; Fournier, M.; Ratajczak, M.; Servais, P.; Petit, F. Assessment of Faecal Contamination and the Relationship between Pathogens and Faecal Bacterial Indicators in an Estuarine Environment (Seine, France). Mar. Pollut. Bull. 2007, 54, 1441-1450. [CrossRef] [PubMed] 
30. Kirschner, A.K.; Kavka, G.G.; Velimirov, B.; Mach, R.L.; Sommer, R.; Farnleitner, A.H. Microbiological Water Quality Along the Danube River: Integrating Data from Two Whole-River Surveys and a Transnational Monitoring Network. Water Res. 2009, 43, 3673-3684. [CrossRef] [PubMed]

31. Brockmann, S.; Piechotowski, I.; Bock-Hensley, O.; Winter, C.; Oehme, R.; Zimmermann, S.; Hartelt, K.; Luge, E.; Nockler, K.; Schneider, T.; et al. Outbreak of Leptospirosis among Triathlon Participants in Germany, 2006. BMC Infect. Dis. 2010, 10, 91. [CrossRef] [PubMed]

32. Huber, S.; Popp, W. Reduction Rates of Pathogenes and Faecal Indicators after UV Disinfection at Bad Tölz Waste Water Treatment Plant; IUVA news: Bethesda, MD, USA, 2003; Volume 3. 